\title{
Factors Affecting Arab Goat Flock Dynamics in Western Lowlands of Ethiopia
}

\author{
Befikadu Zewdie ${ }^{1,2^{*}}{ }^{-}$, Mengistu Urge², Yosef Tadesse², Solomon Gizaw ${ }^{3}$ \\ ${ }^{1}$ Departement of Animal Sciences, Assosa University, Assosa, Ethiopia \\ ${ }^{2}$ School of Animal and Range Sciences, Haramaya University, Dire Dawa, Ethiopia \\ ${ }^{3}$ LIVES Project, International Livestock Research Institute (ILRI), Addis Ababa, Ethiopia \\ Email: ^zewdienati@gmail.com, urgeletta@yahoo.com, yosef.tadesse@gmail.com, s.gizaw@cgiar.org
}

How to cite this paper: Zewdie, B., Urge, M., Tadesse, Y. and Gizaw, S. (2019) Factors Affecting Arab Goat Flock Dynamics in Western Lowlands of Ethiopia. Open Journal of Animal Sciences, 9, 305-323. https://doi.org/10.4236/ojas.2019.93026

Received: May 23, 2019

Accepted: July 9, 2019

Published: July 12, 2019

Copyright (c) 2019 by author(s) and Scientific Research Publishing Inc. This work is licensed under the Creative Commons Attribution International License (CC BY 4.0).

http://creativecommons.org/licenses/by/4.0/

cC) (i) Open Access

\begin{abstract}
The study was conducted to estimate flock dynamics of western lowland Arab goat and to assess their contribution to income of smallholder farmers in Kurmuk and Assosa districts, western Ethiopia. Flocks of 30 households were monitored for a period of 12 months in 2016. Data were analyzed using the general linear model procedure of SAS and two-way interaction effects were fitted in the model and retained when found significant in the preliminary analysis. The study result indicates that total entrances for all flock were significantly $(\mathrm{p}<0.05)$ higher in dry and hot-cool seasons than wet season. Most of the entrance was kids born in hot-cool season (January) $(4.0 \pm 0.42)$ and hot-dry season (May) $(5.4 \pm 1.09)$ for Assosa and Kumruk study sites, respectively. Kid mortality constituted the greater part of outflow. High kid mortality was occurred during July, February, January, and September. Most of the sell of castrated goats were occurred in September and April for both small and large flocks targeting holidays celebrated during this months. Male goat owners had significantly lower goat production potential (GPP) value than female $(0.47 \pm 0.02$ vs. $0.52 \pm 0.02)$. The GPP was lower in small flock than in large flock $(0.48 \pm 0.02$ vs. $0.51 \pm 0.02)$. Higher GPP was recorded in the months of January, February, and March for both large and small flocks. The off-take was higher $(\mathrm{P}<0.05)$ in Assosa $(0.06 \pm 0.01)$ than Kumruk $(0.02 \pm$ $0.02)$ district. The average goat production efficiency (GPE) was higher $(\mathrm{P}<$ 0.05) in Assosa large $(193.23 \pm 20.0)$ and small flocks $(93.44 \pm 17.3)$ than Kumruk large $(84.71 \pm 15.6)$ and small flocks $(33.33 \pm 26.3)$.The production efficiency recorded was not comparable to the potential that the farmers had to sell goats or consume goats' meat and milk. The lower goat production potential observed for small flocks implies that high mortality rates severely restrict receiving higher benefits from goat. Therefore, in order to optimize the productivity of goats flock dynamics, developing health intervention strategies that target reduction of kids' mortality is imperative.
\end{abstract}




\section{Keywords}

Entrance, Exit, Goat, Off-Take, Production Efficiency, Production Potential

\section{Introduction}

Due to the ever-increasing human population and drastically shrinking farmlands, goat production is becoming a means of survival particularly for the landless youth and female headed households. As a result, the contribution of goats is greater in the rural areas of Ethiopia and in other developing countries where they meet economic, socio-cultural, and nutritional need of the resource poor farmers [1].

Despite the significant contribution of goat to the household and national economy of Ethiopia, their productivity is below the expectations, as compared to their numbers. Moreover, slow growth, high mortality, and low commercial off-take rates were the major challenges of smallholder goat production in the country [2] [3]. These could be attributed to the prevalence of diseases that result to high mortality, lack of adequate feed resources, absence of appropriate breeding systems to exploit the diverse genetic potential, and poor access to infrastructural and institutional supports [4] [5]. The research approach has not also invited the end users for active participation. Goat productivity improvement endeavours in Ethiopia were too slow due to lack of in-depth analysis of the actual on-farm situations and understanding the socioeconomic and cultural benefits of the animals to the poor farmers [6]. Nevertheless, with the present knowledge of planned breeding programs, forage production practices, improved animal husbandry techniques, and extension capabilities, much can be done to improve production and productivity of goats in Ethiopia.

Information on the effect of seasonal changes in flock dynamics and management in smallholder production is scarce, making it difficult to assess the efficiency of the contribution of smallholder goat production to its keepers and to the economy of the country. Lack of information also makes it difficult to predict goat sales and consumption patterns under smallholder conditions. Hence, it is crucial to understand the smallholder farm characteristics and farming systems. This requires in-depth research on flock size and structures and seasonal variation so as to quantify the contribution of goats to the livelihood of the smallholder farmers and the national economy. This can be done through monitoring flock dynamics with the participation of farmers [7]. The objective of this study, therefore, was to determine the contribution of goat to the livelihood of resource poor farmers through monitoring of goat flock dynamics in the context of smallholder farm management condition.

\section{Materials and Methods}

\subsection{Study Site and Farmers Selection}

The research was conducted in Western Ethiopia, Assosa zone, Benishangul-Gumuz 
region. Two districts, Assosa and Kumruk were selected purposively from 7 districts of the zone because of high goat density and major areas of concentration of Arab goat breed. Assosa district is located between $10^{\circ} 02.922^{\prime} \mathrm{N}$ latitude and $34^{\circ} 33.868^{\prime} \mathrm{E}$ longitude. The district receives an average rainfall of $950-1000 \mathrm{~mm}$ annually and average temperature of $30^{\circ} \mathrm{C}$ with the hottest season occurring during March and May [8]. The district is characterized by diverse topography with altitude range of 580 - 1544 m.a.s.l. The district is characterized by long rainy season (June-September) accounting for $75 \%$ of the total rainfall, short rainy season (February/March to April/May), and dry season (October-January) [9]. The Kumruk district is located between $10^{\circ} 32^{\prime} \mathrm{N}$ latitude and $34^{\circ} 17^{\prime} \mathrm{E}$ longitude. The district is characterized by mono-modal mean annual rainfall of 800 to $1200 \mathrm{~mm}$ occurring during June to September [9]. The altitude varies from 500 to 1200 m.a.s.l. and the average annual temperature is $33^{\circ} \mathrm{C}$ with the hottest season occurring during March and May.

The monitoring study was conducted in Baro and Horazehab kebeles (the smallest administration level) of Assosa and Kurmuk districts, respectively. The kebeles were purposively selected based on their representativeness with respect to Arab goat population and accessibility for easy and regular monitoring. Selection of farmers was on the basis of owning at least three mature goats, willingness to participate in the study, and presence of a literate member in the household who could keep accurate records. In this study, literacy was defined as the ability to record goat entry and exit into and out of the flocks in the record booklets provided. Thirteen and seventeen households were selected from Baro and Horazehab Kebeles, respectively.

\subsection{Monitoring of Flock Dynamics}

Assessment of goat flock dynamics and productivity were accomplished through conducting monthly visits for one year (January, 2016 to December, 2016). Flocks in each village were classified into small and large. Flocks with more than 13 adult goats were considered large whereas that consists 13 or less were categorized as small flock. Household heads were categorized into two age groups as young ( $\leq 35$ years) and old ( $>35$ years). The goats in a flock were classified into five categories; adult females (female goats older than one year), bucks (entire male older than one year), castrates, female kids (female kids less than one year), and male kids (male kids less than one year). The distributions of goat flock and respondents characteristics and flock structure of goats are presented in Table 1 and Table 2.

\subsection{Production Potential and Efficiency Measures}

Three measures of goat production efficiency were considered in this study, which include off-take rate, goat production potential (GPP), and goat production efficiency (GPE). Off-take in this study was defined as the total number of goats sold, slaughtered, or given out permanently as a proportion of the total 
Table 1. Characteristics of goat keepers and distribution of flocks.

\begin{tabular}{ccccc}
\hline \multirow{2}{*}{$\begin{array}{c}\text { Respondent } \\
\text { Characteristics }\end{array}$} & Large flocks & Small flocks & Large flocks & Small flocks \\
\cline { 2 - 5 } Gender of farmer & 6 & & & \\
Male & 2 & 5 & 2 & 5 \\
Female & & - & 6 & 4 \\
Age of farmer & 4 & 2 & 6 & 5 \\
$\leq 35$ & 4 & 3 & 2 & 4 \\
$>35$ & & & & \\
\hline
\end{tabular}

Table 2. Flock structure of goats (mean number per class).

\begin{tabular}{ccccccc}
\hline & \multicolumn{5}{c}{ Flock structure } \\
\cline { 2 - 7 } & Female kids & Male kids & Female adult & Bucks & Castrate & Flock size \\
\hline Baro village & & & & & & \\
Large flock & $3.25 \pm 0.43$ & $2.00 \pm 0.49$ & $7.75 \pm 0.91^{\mathrm{a}}$ & $5.13 \pm 0.39^{\mathrm{a}}$ & $1.75 \pm 0.54$ & $19.88 \pm 1.36^{\mathrm{a}}$ \\
Small flock & $1.80 \pm 0.54$ & $2.40 \pm 0.62$ & $3.80 \pm 1.45^{\mathrm{b}}$ & $2.20 \pm 0.50^{\mathrm{b}}$ & $0.00 \pm 0.68$ & $10.20 \pm 1.73^{\mathrm{b}}$ \\
p-value & 0.061 & 0.623 & 0.021 & 0.001 & 0.069 & 0.001 \\
Horazehab village & & & & & & \\
Large flock & $2.00 \pm 0.41$ & $1.88 \pm 0.33$ & $7.25 \pm 0.50^{\mathrm{a}}$ & $4.38 \pm 0.45^{\mathrm{a}}$ & $2.25 \pm 0.31^{\mathrm{a}}$ & $17.75 \pm 0.93^{\mathrm{a}}$ \\
Small flock & $1.33 \pm 0.41$ & $1.33 \pm 0.31$ & $4.89 \pm 0.47^{\mathrm{b}}$ & $2.44 \pm 0.42^{\mathrm{b}}$ & $0.56 \pm 0.29^{\mathrm{b}}$ & $10.56 \pm 0.88^{\mathrm{b}}$ \\
p-value & 0.253 & 0.248 & 0.004 & 0.007 & 0.001 & $<.0001$ \\
\hline
\end{tabular}

${ }^{\mathrm{ab}}$ Values within a column for a particular village with different superscripts are significantly different $(\mathrm{P}<$ $0.05)$.

flock size [10]. The GPP and GPE for each flock were calculated every month as described by [11]. The GPP was computed as the proportion of mature and growing goats to the total flock size $\left(G P P=\frac{N}{H}\right)$; where, $N=$ number of mature and growing goats; $\mathrm{H}=$ the number of total flocks. The GPE was defined as the proportion of mature goats sold and/or slaughtered for consumption as a proportion of GPP $\left(\left(\frac{M}{G P P}\right) \times 100\right)$, where $M=$ number of mature goats sold and/or slaughtered for consumption.

\subsection{Data Analysis}

Analysis of the parameters and the effects of season, village, gender, and age of head of household and flock size on entries, exits, GPP, GPE, and off-take were determined using the general linear model procedure of SAS [12] adapted from [7] and a two-way interaction effects were also fitted in to the models and retained in the final model when found significant $(\mathrm{P}<0.05)$ in the preliminary analysis. The model used was as follows: 


$$
Y_{i j k l m}=\mu+M_{i}+V_{j}+S_{k}+A_{l}+F_{m}+\sum_{i j k l m},
$$

where: $Y_{i j k l m}=$ response variable (kid mortality, adult mortality, sales, slaughters, goats entrusted out (goat given out from the flock/given to someone's (delegates) to care), births, purchases, exchanges, goats entrusted in, gifts in, gift out, number of goats missing (stolen, eaten by predator, died), GPE, GPP, off-take rate); $\mu=$ constant mean common to all observations; $M_{i}=$ effect of month ( $i=$ January, 2016-November, 2016); $V_{j}=$ effect of village ( $j=$ Baro, Horazehab); $S_{k}=$ effect of gender of farmer ( $k=$ male, female); $A_{I}=$ effect of age group ( $I=$ $\leq 35,>35) ; F_{m}=$ effect of flock size ( $m=$ small flocks, large flocks); $\sum_{i j k l m}=$ random residual error, assumed to be normally distributed.

\section{Results}

\subsection{Flock Sizes and Structure}

Goat numbers per household in both villages varied among months regardless of flocks size (Figure 1), and it was smaller during the period of January to May. All flock sizes started to increase in the month of May and continued to increase till December. The highest flock sizes were recorded in cool-hot season (October and December) in Baro and wet season (July and August) in Horazehab villages. A buck to does' ratio was 1:14.

\subsection{Factors Affecting Entries}

Village has no effect $(\mathrm{p}>0.05)$ on the number of goats that were entrusted, gifted, and exchanged (Table 3). However, the number of goats that entered flocks through birth and purchase were significantly affected by village. The total inflows were also significantly affected by month and interaction between village and month. The pattern of birth inflows was higher during January and August in Baro and in May and June in Horazehab (Figure 2). There was a general decrease

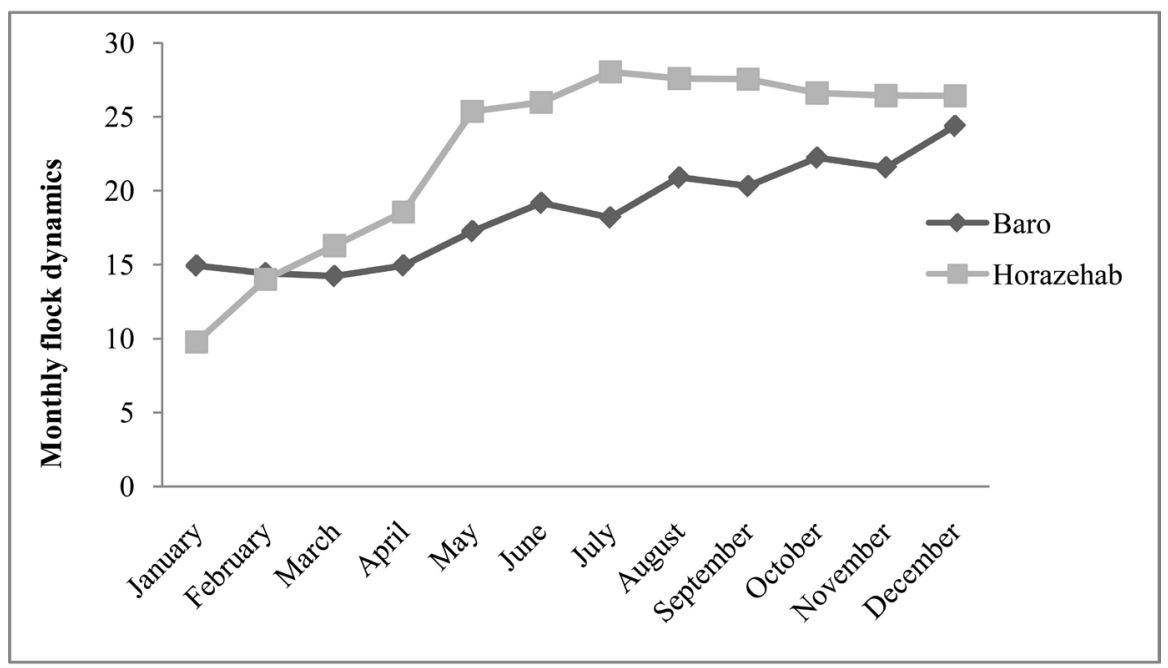

Figure 1. Monthly flock dynamics (January 2016 to December 2016) in Baro and Horazehab villages. 
Table 3. Least square means $( \pm S E$ ) for effect of village on goat production potential and efficiency, off-take, entries, and exits

\begin{tabular}{|c|c|c|c|}
\hline \multirow{2}{*}{ Characteristics } & \multicolumn{2}{|c|}{ Village } & \multirow{2}{*}{$P$-value } \\
\hline & Baro & Horazehab & \\
\hline \multicolumn{4}{|l|}{ Entries } \\
\hline Births & $2.98 \pm 0.13^{\mathrm{a}}$ & $1.60 \pm 0.32^{\mathrm{b}}$ & 0.042 \\
\hline Purchases & $0.33 \pm 0.05^{\mathrm{a}}$ & $0.03 \pm 0.12^{\mathrm{b}}$ & 0.035 \\
\hline Goat received as gifts & $0.01 \pm 0.01$ & - & 0.458 \\
\hline Goat Entrusted in & $0.08 \pm 0.02$ & - & 0.168 \\
\hline Goat received as exchange & $0.01 \pm 0.01$ & - & 0.789 \\
\hline \multicolumn{4}{|l|}{ Exits } \\
\hline Sales & $0.89 \pm 0.08^{\mathrm{a}}$ & $0.29 \pm 0.19^{b}$ & 0.004 \\
\hline Slaughters & $0.19 \pm 0.18$ & $0.17 \pm 0.03$ & 0.828 \\
\hline Missing & $0.11 \pm 0.03$ & $0.09 \pm 0.06$ & 0.741 \\
\hline Deaths & $0.42 \pm 0.07$ & $0.64 \pm 0.16$ & 0.219 \\
\hline Goats given as gifts & $0.05 \pm 0.04$ & - & 0.193 \\
\hline Goats entrusted out & $0.03 \pm 0.01$ & $0.01 \pm 0.03$ & 0.465 \\
\hline Goats given out as exchange & $0.01 \pm 0.01$ & $0.01 \pm 0.02$ & 0.877 \\
\hline GPP & $0.49 \pm 0.01$ & $0.50 \pm 0.01$ & 0.596 \\
\hline GPE & $241.96 \pm 29.06^{\mathrm{a}}$ & $52.59 \pm 71.38^{\mathrm{b}}$ & 0.016 \\
\hline Off-take & $0.06 \pm 0.01^{\mathrm{a}}$ & $0.02 \pm 0.01^{\mathrm{b}}$ & 0.007 \\
\hline
\end{tabular}

${ }^{\mathrm{ab}}$ Values within a row with different superscripts are significantly different. SE = standard errors; GPP = Goat production potential; GPE $=$ Goat production efficiency.

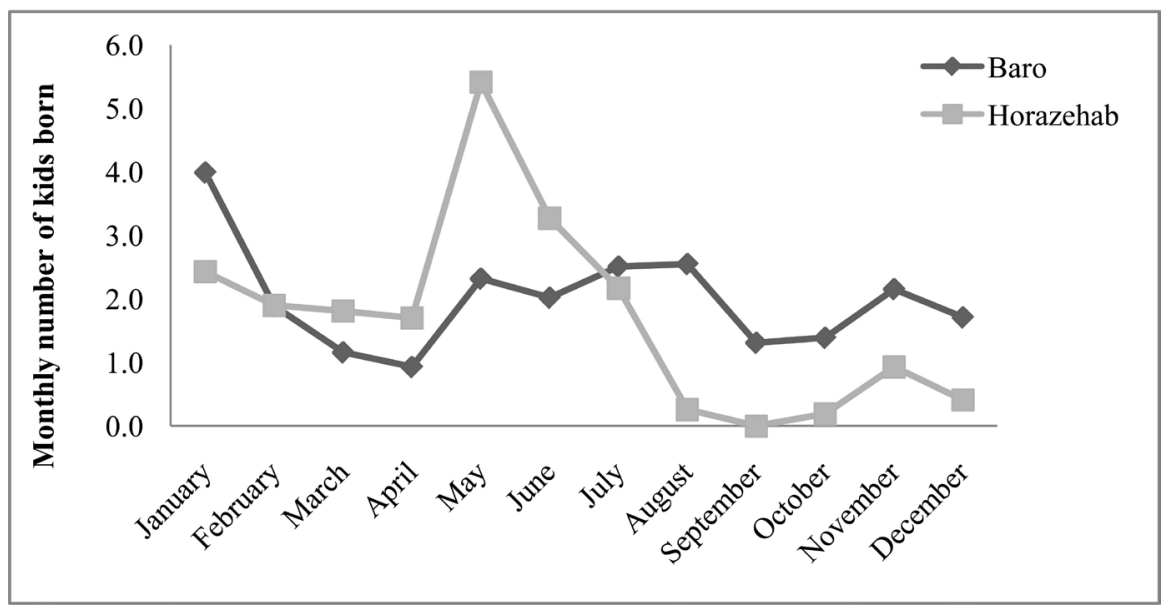

Figure 2.Mean monthly births in Baro and Horazehab villages.

in goat number between February to April and July to September for both Baro and Horazehab villages, but the increase and decrease in flock size in other months was irregular having no apparent trend. In general, most of the entrances of kids were those born in cool-dry season (January) and hot-dry season 
(May and June) in Baro and Horazehab, respectively.

The presence or absence of buck in a flock has an effect on the number of kids in the flock. Flocks without bucks had $6.65 \pm 0.25$ kids compared to $7.12 \pm 0.24$ kids in flocks that have buck running with the flock at all the time. The presence of bucks in a flock was positively correlated with inflow of kids due to mating at appropriate time. The highest ratio of bucks to does was observed during hot-dry season (May and June) with equal value of 1:16 (Figure 3). Relatively higher ratio of bucks to does were observed in wet season (July) followed by dry season (April). Season has significant effect on the proportion of kids to does in the flock. The proportions of kids to does started to increase from cool-dry season (January up to December), but higher increment was recorded during cool-dry season (December and November) than in the other seasons (Figure 3).

\subsection{Factors Affecting Purchase}

Total goat purchase was significantly affected by village and flock size, but not by age and sex of farmer, and season (Table 4). The number of goats procured was significantly higher in Baro than Horazehab and by large flock owners than small flock. The number of bucks purchased was significantly affected by sex of the head of the households and village only (Table 4). The female headed owners bought greater number $(\mathrm{P}<0.05)$ of bucks than male owners. Breeding buck was purchased by some goat owners in Baro, but buck purchase was not recorded in Horazehab village during the study period. The number of breeding female purchased was affected by month $(P<0.01)$ and flock size $(P<0.05)$. Interaction effect exists between village and month on the purchase of females (Figure 4). Most of the purchases were done in January, October, March, May, and April than other months in Baro whereas May, August, and April were the months during which purchase were greater in Horazehab village. However, female goat

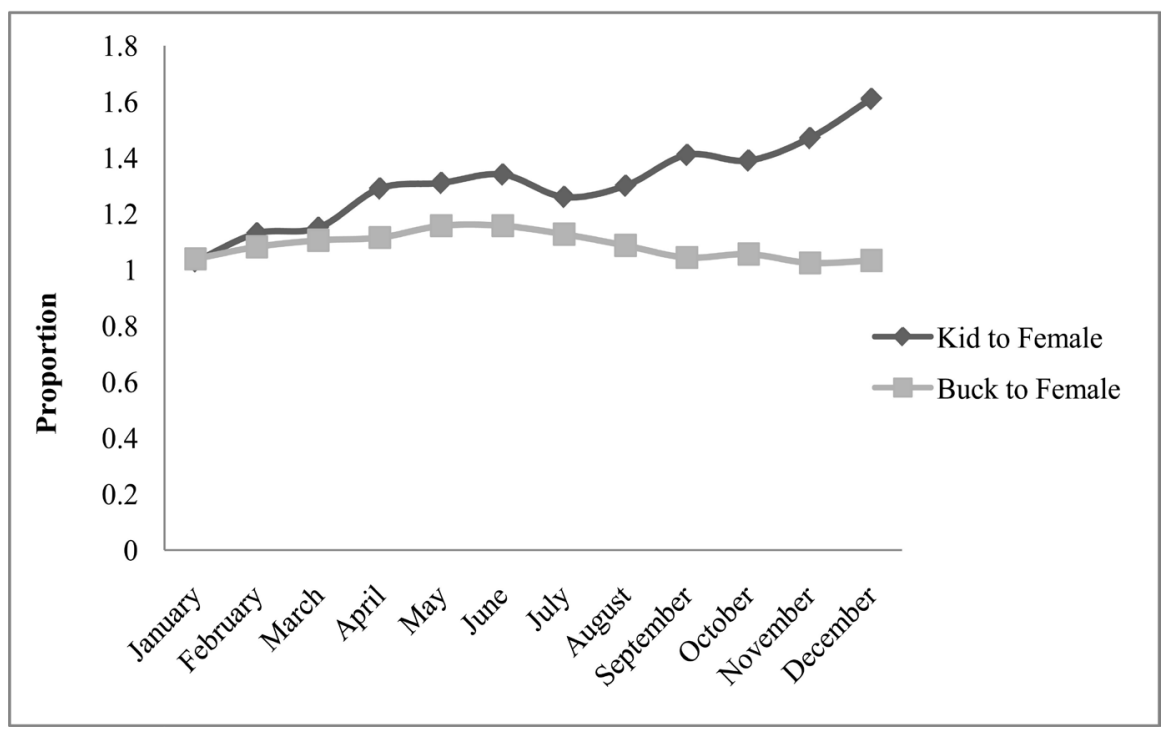

Figure 3. Proportions of kid to does and buck to does ratio in Baro and Horazehab villages. 
Table 4. Least squares means $( \pm \mathrm{SE}$ ) for effects of sex, age of household head, flock, village, and month on total number of Arab goat and buck purchase.

\begin{tabular}{|c|c|c|}
\hline Effects/levels & Total purchased goat & purchased buck \\
\hline Overall & $0.25 \pm 0.87$ & $0.10 \pm 0.39$ \\
\hline $\mathrm{N}$ & 360 & 360 \\
\hline \multicolumn{3}{|c|}{ Gender of farmer } \\
\hline Male & $0.09 \pm 0.08$ & $0.01 \pm 0.03^{\mathrm{a}}$ \\
\hline Female & $0.27 \pm 0.10$ & $0.11 \pm 0.04^{\mathrm{b}}$ \\
\hline$p$-value & 0.136 & 0.029 \\
\hline \multicolumn{3}{|l|}{ Age of farmer } \\
\hline$>35$ & $0.07 \pm 0.09$ & $0.02 \pm 0.04$ \\
\hline$<35$ & $0.29 \pm 0.10$ & $0.10 \pm 0.04$ \\
\hline$p$-value & 0.0561 & 0.101 \\
\hline \multicolumn{3}{|l|}{ Flock size } \\
\hline Small & $0.07 \pm 0.09^{\mathrm{b}}$ & $0.02 \pm 0.04$ \\
\hline Large & $0.29 \pm 0.08^{\mathrm{a}}$ & $0.10 \pm 0.04$ \\
\hline$p$-value & 0.027 & 0.100 \\
\hline \multicolumn{3}{|l|}{ Month } \\
\hline January & $0.17 \pm 0.26$ & $0.09 \pm 0.12$ \\
\hline February & $0.25 \pm 0.26$ & $0.08 \pm 0.12$ \\
\hline March & $0.24 \pm 0.23$ & $0.07 \pm 0.11$ \\
\hline April & $0.12 \pm 0.23$ & $0.03 \pm 0.11$ \\
\hline May & $0.12 \pm 0.23$ & $0.06 \pm 0.11$ \\
\hline June & $0.09 \pm 0.23$ & $0.05 \pm 0.11$ \\
\hline July & $0.04 \pm 0.23$ & $0.01 \pm 0.11$ \\
\hline August & $0.14 \pm 0.23$ & $0.09 \pm 0.11$ \\
\hline September & $0.13 \pm 0.23$ & $0.07 \pm 0.11$ \\
\hline October & $0.16 \pm 0.23$ & $0.06 \pm 0.11$ \\
\hline November & $0.19 \pm 0.23$ & $0.11 \pm 0.11$ \\
\hline December & $0.50 \pm 0.23$ & $0.01 \pm 0.11$ \\
\hline$p$-value & 0.993 & 0.998 \\
\hline \multicolumn{3}{|l|}{ Village } \\
\hline Baro & $0.33 \pm 0.05^{\mathrm{a}}$ & $0.13 \pm 0.02^{\mathrm{a}}$ \\
\hline Horazehab & $0.03 \pm 0.12^{\mathrm{b}}$ & $0.00 \pm 0.04^{\mathrm{b}}$ \\
\hline$p$-value & 0.035 & 0.0014 \\
\hline
\end{tabular}

${ }^{a b}$ Values within a column with different superscripts are significantly different $(\mathrm{P}<0.05) . \mathrm{SE}=$ Standard error; N: Number. 
purchase was not happen during March, June, July, September, October, November, and December in Horazehab village. Greater numbers of does were purchased in May and January than other months in both villages.

\subsection{Factors Influencing Outflow of Goats}

Kid mortality was significantly $(\mathrm{P}<0.01)$ higher than adult mortality throughout the study period, except in January (Figure 5). High kid mortalities were documented in the dry (February), wet (July and September), and cool (January and November) seasons.

Sell of castrates was significantly affected $(\mathrm{P}<0.05)$ by village and flock. There was significant interaction effect of month and flock size on sell of castrated goats $(\mathrm{P}<0.05)$. The major sell seasons of castrated goats in large flock was April followed by September while it was in September followed by February in small

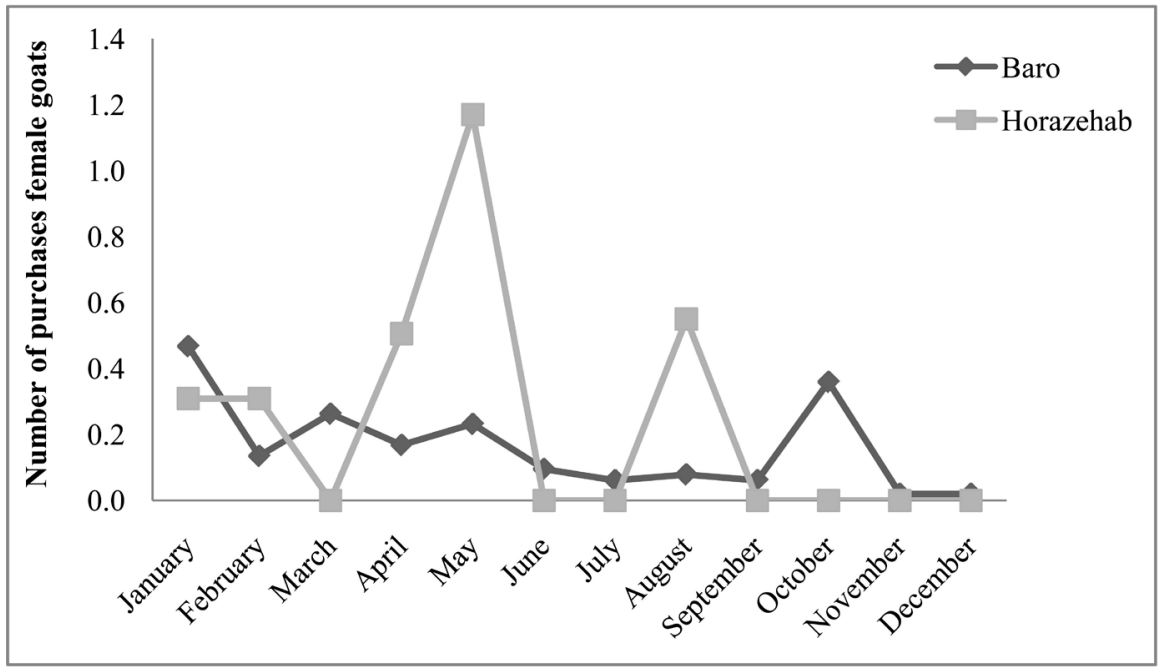

Figure 4. Monthly total purchases of females in Baro and Horazehab villages.

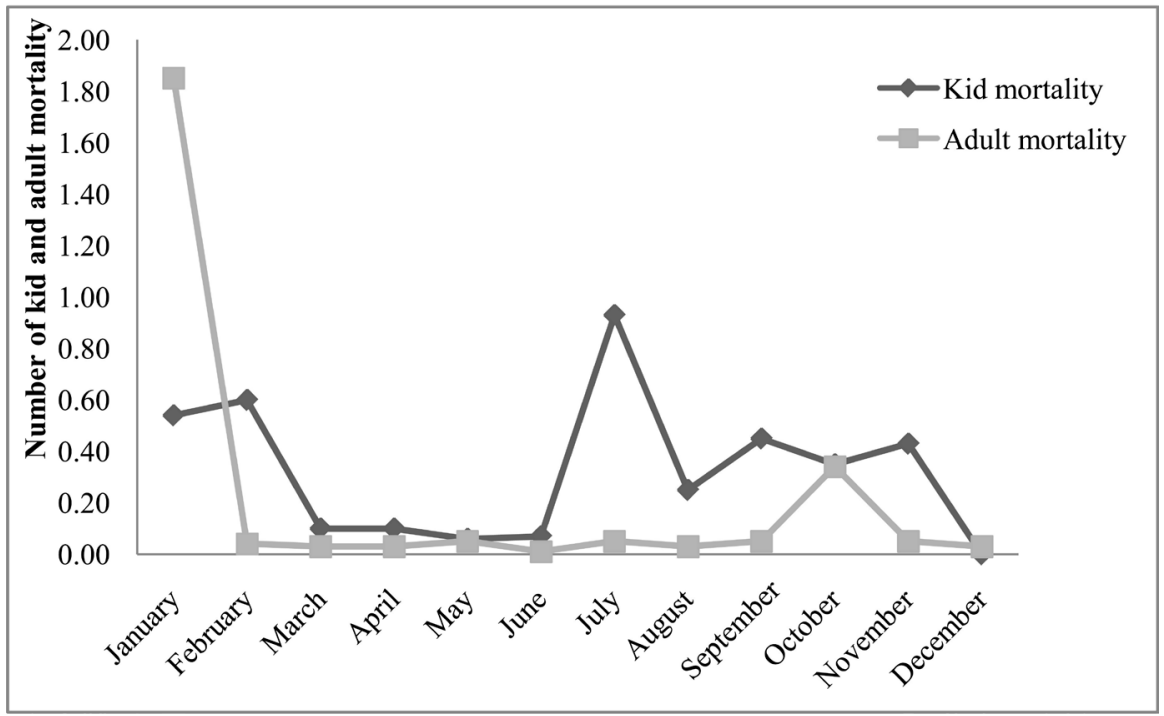

Figure 5. Monthly kid and adult mortality in Baro and Horazehab villages. 
flocks (Figure 6). Most of the goat sells occurred during wet and cool-dry (September and October) and dry season (February and April) for large and small flocks. However, selling of castrated bucks decreased from dry (March) to wet (July) seasons for both small and large flocks. Sells of other classes of goat like kids and female were not affected by all factors.

Total sells of goats was affected by Village $(\mathrm{P}<0.01)$ and flock size $(\mathrm{P}<0.01)$. Significantly more number of goats were sold in Baro than Horazehab village and in large than small flocks (Table 5). Most farmers do not sell female goats unless they were unhealthy, poor in productivity, and very old. Slaughter of goats during the study period was significantly $(\mathrm{P}<0.01)$ affected by month (Table 5$)$. Most of the goat slaughter was during December, April, June, and July.

\subsection{Factors Affecting Off-Take Rate, Goat Production Potential, and Efficiency}

The GPP is significantly affected by gender of owner of goats $(\mathrm{P}<0.022)$ and flock size $(\mathrm{P}<0.034)$. Female owners had higher GPP value than male. The GPP for small flocks was lower as compared to large flocks. Month also significantly affected GPP (Figure 7). The highest $(\mathrm{P}<0.01)$ GPP were recorded in January, February, and March for both flocks. Slaughter decreased from mid-March to May and the lowest slaughter was noted in November and December for both flocks. Village significantly affected off-take and GPE (Table 3). The off-take and GPE were higher $(\mathrm{P}<0.002 ; \mathrm{P}<0.01)$ in Baro village than in Horazehab. The GPE was also affected $(\mathrm{P}<0.001)$ by flock size (Figure 8$)$. The GPE were higher in Baro small and Baro large flocks than Horazehab small and large flocks.

\section{Discussion}

Although studies on the effects of seasonal changes on flock dynamics and management is scarce in Ethiopia, some studies [7] [13] [14] highlighted the effect of this factor in communal areas of African countries. Lack of information

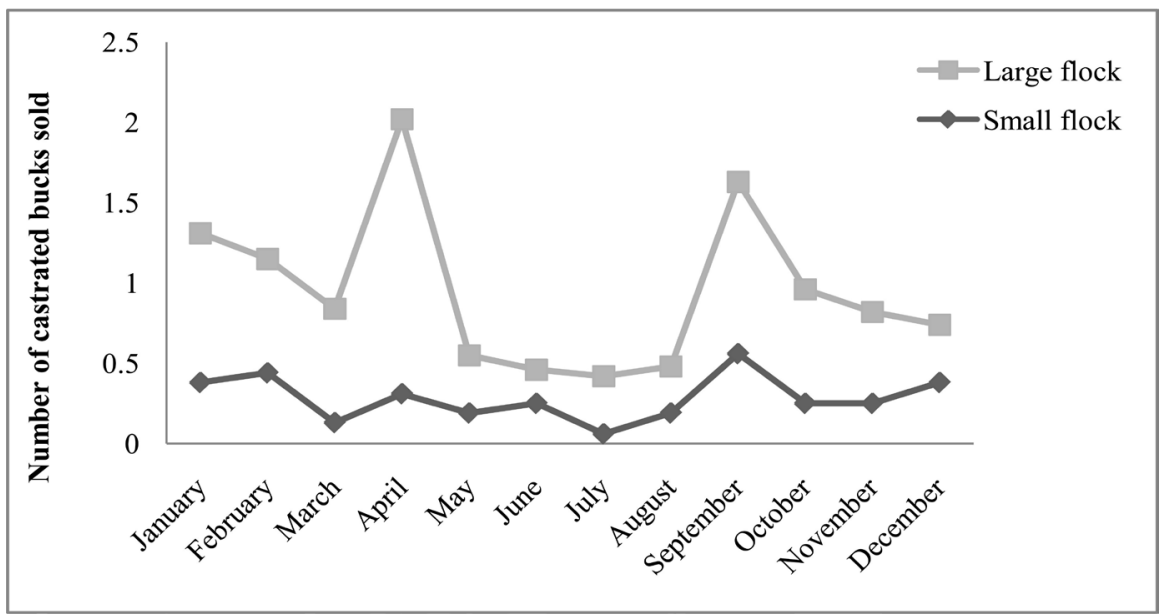

Figure 6. Monthly total sells of castrates in small and large flocks in Baro and Horazehab villages. 
Table 5. Least squares means ( \pm SE) for effects of sex, age, flock, village, and season on total number of sell and slaughter of Arab goat.

\begin{tabular}{|c|c|c|}
\hline Effects/ levels & Sell & Slaughter \\
\hline Overall & $0.78 \pm 1.24$ & $0.19 \pm 0.50$ \\
\hline $\mathrm{N}$ & 360 & 360 \\
\hline \multicolumn{3}{|l|}{ Gender of farmer } \\
\hline Male & $0.66 \pm 0.12$ & $0.17 \pm 0.05$ \\
\hline Female & $0.52 \pm 0.14$ & $0.19 \pm 0.06$ \\
\hline$p$-value & 0.409 & 0.739 \\
\hline \multicolumn{3}{|l|}{ Age of farmer } \\
\hline$>35$ & $0.52 \pm 0.12$ & $0.21 \pm 0.05$ \\
\hline$<35$ & $0.68 \pm 0.14$ & $0.15 \pm 0.05$ \\
\hline$p$-value & 0.407 & 0.358 \\
\hline \multicolumn{3}{|l|}{ Flock size } \\
\hline Small & $0.24 \pm 0.13^{\mathrm{b}}$ & $0.18 \pm 0.05$ \\
\hline Large & $0.93 \pm 0.12^{\mathrm{a}}$ & $0.18 \pm 0.05$ \\
\hline$p$-value & $<.0001$ & 0.948 \\
\hline \multicolumn{3}{|l|}{ Season } \\
\hline January & $0.48 \pm 0.38$ & $0.09 \pm 0.10^{c}$ \\
\hline February & $0.86 \pm 0.38$ & $0.12 \pm 0.10^{\mathrm{bc}}$ \\
\hline March & $0.25 \pm 0.37$ & $0.06 \pm 0.10^{c}$ \\
\hline April & $0.72 \pm 0.34$ & $0.39 \pm 0.10^{\mathrm{ab}}$ \\
\hline May & $0.24 \pm 0.34$ & $0.09 \pm 0.10^{c}$ \\
\hline June & $0.46 \pm 0.34$ & $0.29 \pm 0.09^{\mathrm{bc}}$ \\
\hline July & $0.35 \pm 0.34$ & $0.26 \pm 0.09^{\mathrm{bc}}$ \\
\hline August & $0.57 \pm 0.34$ & $0.06 \pm 0.10^{c}$ \\
\hline September & $1.06 \pm 0.34$ & $0.06 \pm 0.10^{c}$ \\
\hline October & $0.63 \pm 0.34$ & $0.12 \pm 0.10^{\mathrm{bc}}$ \\
\hline November & $0.85 \pm 0.34$ & $0.06 \pm 0.10^{c}$ \\
\hline December & $0.58 \pm 0.34$ & $0.59 \pm 0.10^{\mathrm{a}}$ \\
\hline$p$-value & 0.871 & 0.0002 \\
\hline \multicolumn{3}{|l|}{ Village } \\
\hline Baro & $0.89 \pm 0.08^{\mathrm{a}}$ & $0.19 \pm 0.03$ \\
\hline Horazehab & $0.29 \pm 0.19^{\mathrm{b}}$ & $0.17 \pm 0.07$ \\
\hline$p$-value & 0.004 & 0.828 \\
\hline
\end{tabular}

${ }^{a b}$ Values within a column with different superscripts are significantly different.SE: standard error; N: Number. 


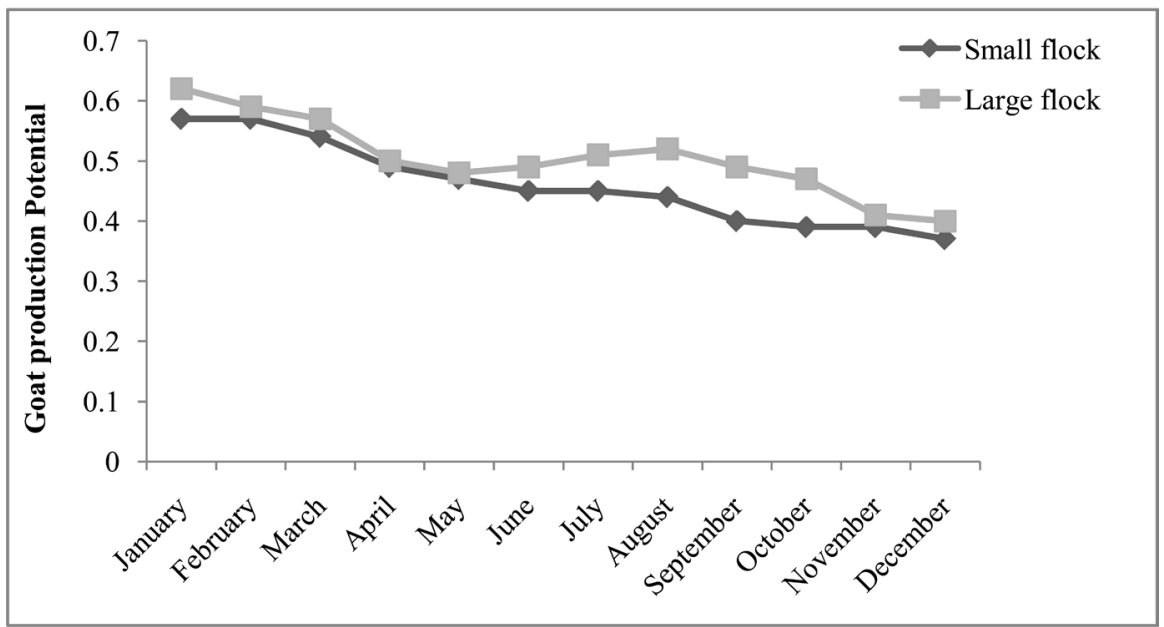

Figure 7. Effect of month on small and large flocks Arab goat production potential.

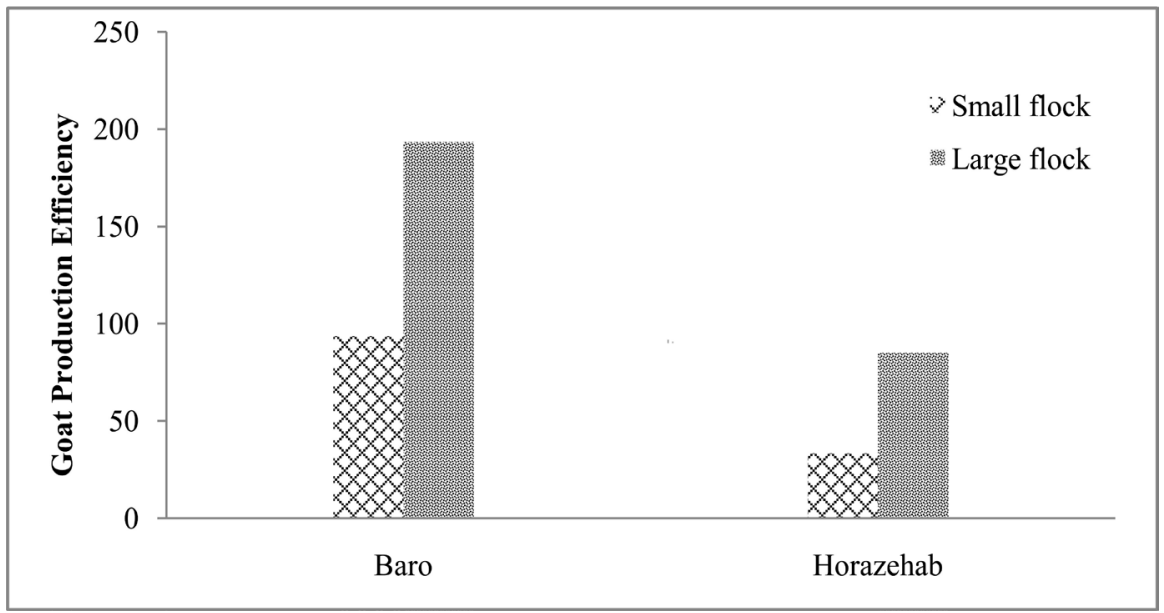

Figure 8. Effect of village on small and large flock Arab goat production efficiency.

makes prediction of goat sells and consumption patterns difficult in the communal areas. Moreover, assessment of the efficiency of contribution of communal goat production to household income and nutrition, and the economy of the country requires data on flock dynamics and factors affecting this. The finding that flock inflow is affected by seasons is attributed to the variation in the availability of forage in sufficient quantity and quality. Higher inflow of kids were observed in January and August which is directly related to higher conception in main rainy season (August) and short rainy season (March). In both seasons, feed is available and as a result the doe come to heat and conceive. Similarly, [3] noted that flock dynamics was affected by land and feed scarcity and family and farm size in southern Ethiopia. [13] also stated that sheep flock inflow was affected by month in South Africa communal farming system.

The higher number of entries through birth agrees with previous study [3]. The high total entries through home born kids was also consistent with reports of [15], but higher than other reports [16]. In the current study, female goats constituted about $54 \%$ of the flock. The higher female number in a flock is re- 
lated to the need of owners to ensure sustainable household income and milk for family consumption by maintaining high number of does and keeping fewer numbers of intact males for breeding, and castrates for finishing. This result was in agreement with previous studies [7] [13] [17] [18]. Much greater proportion of female animals (70\%) in sheep herd was also reported by [19] in the Northern Highlands of Ethiopia and [20] in the traditional goat flocks of Swaziland. This shows that different communities have their own breeding objectives based on the interest of the household and the environment. As [21] indicated, a breeding objective defines the direction in which the farmer would like to go towards satisfying his demand for specific products and services from the animals.

Birth, purchase, and gifts were the routes of entry into the flocks. Nevertheless, birth was the major route of goat inflows in both Baro and Horazehab villages which implicates the importance of feeding for timely conception and sustainable reproduction in the flock. Different studies [22] [23] [24] indicated the positive relationship of breeding season and feed availability for goats in Ethiopia.

The recommended buck to doe ratio for goats under traditional production system is 1:25 [25]. The buck to doe ratio obtained in the present study was lower than the recommended rate, which can be considered as a good practice, since increased number of breeding males in the flock enhances birth inflows as a result of effective mating that can occur in the presence of sufficient number of bucks. In the contrary, in order to avoid inbreeding in the flock it is useful to maintain the standardized buck to doe ratio. As number of breeding male increase and number of breeding female decrease, the flock would be exposed for high rate of inbreeding. Hence, at higher levels of inbreeding, wastage rates will also be higher, due to reduced fitness and the culling of animals with deleterious genes. Breeding opportunities may be limited if available bucks are closely related to a large proportion of female population. Under such circumstances, it may become increasingly difficult to maintain the flock performance due to decreasing effective population size and inbreeding depression [26]. However, in the current study it was observed that males were removed from the flock at early age (about a year and half) resulting in reduced proportion of males and absence of males in some flocks at various times. Shortage of intact males in a mixed flock was also observed during the monitoring period. Nevertheless, due to uncontrolled breeding flocks from different respondents were herd together in the village and the scarcity of breeding male buck was reduced. Besides, farmers in the study area take females to the nearby villages when there was shortage of intact males in the flock. Intact male sharing for reproduction was also reported in previous studies [23] [25] [27]. On the other hand, goats from different flocks do not mix during the cropping season since they were herded in different areas away from crop fields suggesting that reproductive performance of flocks without bucks were affected. According to [23] male goats greater than one year are frequently sold whenever cash is needed in the household, which implicate the disturbance of effective population size in the flocks and as a con- 
sequence rate of inbreeding may be increased. Hence, farmers should be advised to have at least a buck available in the flock.

The decreasing goat number between July to September and February to April could be ascribed to goat sells as well as adult mortality that mostly occurred during September and October and February and April. The peak period of selling was observed in September and February for small flocks and April and September for large flocks. April and September were peak period of selling for small and large flocks, respectively because of high goat demand in April and September since it is the month of Ethiopian Easter, and New Year and Meskel (the founding of the Holly cross) celebrations, respectively. During this period, the demand for small ruminant meat is high and the price is relatively attractive to producers. September is also the month in which school is opened and farmer's money need is high due to the miscellaneous school fee payments. Depending on locations, the sale months reported for different studies may vary and some studies found more than $40 \%$ of the exits of goats to occur through sell in the months of February, May, and August [27]. In general, earlier studies [16] [24] noted high number of exits of small ruminants through sell for the purchase of agricultural inputs, miscellaneous expenses for school children, and to buy commodities for home consumption.

The higher sales of castrated male goats during holidays in the current study were consistent with previous reports [4] [13] [28] in South Africa and Ethiopia, respectively. Slaughtering of goat was at the peak in the dry-cool season (December) since it was the time of Muslim holidays (Id al Mauled, birth of prophet Mohammed), which concurs very well with earlier work [27] [29] that reported similar trend in cattle and goat marketing. However, farmers fetched low price during the cool and dry season due to poor body condition. These findings also concur with the observations by [30] who established that goats are mainly kept for ceremonies and for slaughter during the festive season and are therefore sold in June and December. In other studies [16] [23] [24] who have confirmed that goats are rarely slaughtered outside a ceremonial context in most places in Ethiopia. In addition to the high sell months (April, September, and December) farmers also sold goats in August to buy agricultural inputs and food, however farmers sold their goat at any month when there was an urgent need for cash.

The fact that almost one quarter of the goat for sell originated from small flocks shows that although they have limited resources of inputs, these farmers make a significant contribution to the market. They consequently produced more goats and sold in relation to their flock size. Nevertheless, they also faced relatively high mortality rates in comparison to production rates. The finding of higher mortality was observed in small flock which is in line with the findings of previous studies [7] [13].

In the current study kid mortality was higher than adult mortality. The average mortality rate in all stocks obtained in the present study were also close to the average mortality rates reported in Tanqua Abergelle districts of central Ti- 
gray zone, northern Ethiopia [22] [28] [31]. During the study, farmers argued that resource-poor farmers cannot easily get information and inputs and thus less capable of preventing goat mortalities. This is a strong argument to support interventions to reduce goat mortality [22] as this would increase the number of animals available for sell. The high kid mortalities during February and July months are because of inability of does to provide enough milk since the does were affected with disease. The observation that kid mortality was the major exits from both flock sizes might be due to different causes, which needs critical intervention strategy. Although the causes of kids mortality were not quantified accurately, high kid mortality in dry season compared to wet could be due to feed availability to does during wet seasons. This finding is similar with earlier reports by [32] [33] for Borana and Aris-Bale in Ethiopia and Sudan, respectively and [34] for Begit and Abergelle goats that indicated lower survival rate of kids born in the dry than wet season. Relatively high disease and parasite infestation of animals including goats were common in low land probably due to the presence of communal and movement of animals [22] and less information available on the prevalence of diseases [28]. Therefore, this result suggests the need to develop health interventions to reduce mortality of kids and optimize productivity of goats. In addition, most farmers find it difficult to identify some of the diseases and hence training of farmers in animal health could be an appropriate intervention.

The low value obtained for off-take in Horazehab than in Baro village indicates the number of goats that exited the flocks through sells and/or slaughters as a proportion of the whole flocks, which was inclusive of kids. Higher rates of male off-take were recorded during the study period, the majority being removed from the flock before a year and half. Some key informants suggested that only few males are required for breeding and others should be disposed off through sell since feed shortage is a problem and insufficient resource base for fattening.

Goat production potential was lower in small flocks than in large flocks. The fact that the lower goat production potential observed for small flocks implies that high mortality rates severely restrict farmers with small flocks from deriving higher benefits from goat. [35] reported high proportion of lose of goats due to mortality in households with small flocks, which is in agreement with the present finding. A continuous need of cash to solve immediate problems make farmers of small flock holder not to build up flocks to sustainable size and remain with low goat production [7]. Although goats were a major component of the livestock species, they were not viewed as one of a primary resource for food security or income generating entity, which explains the consistently low production potential across all the seasons. Only $27.35 \%$ and $9.63 \%$ of the potential of flocks of goat was utilized through sells and consumption, respectively. The implication of this is that interventions that aim at increasing the supply of goat to the market need to target resource poor farmers. The results of this study was 
supported by [28] who reported that improved goat production and marketing program would eradicate poverty and at the same time building a sustainable food security option for communal communities. However, causes of kids' mortality in this study were not adequately monitored, since farmers in Baro and Horazehab did not sent dead kids for post-mortem examination. Veterinary service, nutrition supply, and housing structure support for goat in the communal areas was quite weak and could be some of the causes for high kid mortality. The already low carrying capacity of the pastureland could not sustain additional flock stock and thus inadequate nutritional supply would result in reduction of reproductive performance. This effect of under-nutrition causes disruption in endocrinology thereby lowering the overall flock productivity of goats. The results of this study were supported by previous work [36] [37] [38] who reported that paying more attention to rearing management systems, improve health condition, and supply of adequate nutrients could improve reproduction. Thus, identifying the common types of goat rearing system, practice of management of flock size, and available feed to Arab goats could help in improving the growth and economic performance of goat production.

In this study, large flocks have larger GPE which could be attributed to the fact that large flocks could dispose more goats than small flocks. The farmers with large flocks probably have tried to reduce flock to manageable sizes [7]. Greater GPP and GPE in larger than small size flock indicate that a higher number of mature and growing goat were sold by owners of large flocks. The production efficiency obtained in this study was not comparable to the potential that the farmers had to sell or consume goats.

\section{Conclusion}

The preference for goat farming in the study area is attributed to the fact that they are considered as the main income source for the family due to the relative ability to tolerant disease and drought as compared to other livestock species. The major constraints to goat in the study area includes inadequacy of goat management knowledge, shortage of feed, low off take rates, inefficiency due to poor marketing, high mortality due to diseases, and low reproductive performance due to inadequate supply of nutrition. Various factors have influenced the benefits that can be obtained from goat selling and consumption suggesting the need for strategic approach to reduce the influence of factors such as season, month, and location on goat production and productivity.

\section{Conflicts of Interest}

The authors declare no conflicts of interest regarding the publication of this paper.

\section{References}

[1] Halima, H., Michael, B.M., Rischkowsky, B. and Tibbo, M. (2012) Phenotypic Cha- 
racterization of Ethiopian Indigenous Goat Populations. African Journal of Biotechnology, 11, 13838-13846.

https://www.ajol.info/index.php/ajb/article/view/129323

[2] Solomon, A.K., Mwai, O., Grum, G., Haile, A., Rischkowsky, B., Solomon, G. and Dessie, T. (2014) Review of Goat Research and Development Projects in Ethiopia. International Livestock Research Institute (ILRI) Project Report, Nairobi.

[3] Talore, D.G., Abebe, G. and Tegegne, A. (2015) The Influence of Nongenetic Factors on Early Growth of Halaba Kids under Smallholder Management Systems, Southern Ethiopia. Experimental Agriculture, 51, 344-354. https://doi.org/10.1017/S0014479714000349

[4] Gizaw, S., Tegegne, A., Gebremedhin, B. and Hoekstra, D. (2010) Sheep and Goat Production and Marketing Systems in Ethiopia: Characteristics and Strategies for Improvement. IPMS (Improving Productivity and Market Success) of Ethiopian Farmers Project Working Paper 23. ILRI (International Livestock Research Institute), Nairobi.

[5] Solomon, A.G. (2014) Design of Community Based Breeding Programs for Two Indigenous Goat Breeds of Ethiopia. PhD Thesis, University of Natural Resources and Applied Life Sciences, Vienna.

[6] Woldu, T. (2016) Optimizing Community-Based Breeding for Indigenous goat Breeds in Ethiopia. PhD Thesis, University of Hohenheim, Stuttgart-Hohenheim, 67-71.

[7] Gwaze Rumosa, F., Chimonyo, M. and Dzama, K. (2009) Communal Goat Production in Southern Africa. Tropical Animal Health Production, 41, 1157-1168. https://doi.org/10.1007/s11250-008-9296-1

[8] Assefa, T., Samson, L. and Samuel, D. (2015) Prevalence of Donkey Trypanosomosis in Assosa District, Benishangul-Gumuz Regional State, Northwest Ethiopia. Acta Parasitologica Globalis, 6, 147-153.

[9] ASARC (Assosa Agriculture Research Center) (2011) Results of Farming System Survey Benshangul-Gumuz Regional State. Ethiopian Institute of Agricultural Research, Assosa.

[10] Wilson, R.T. (1986) Livestock Production in Central Mali: Long-Term Studies on Cattle and Small Ruminants in the Agropastoral System. ILCA Research Report 14, ILCA (International Livestock Centre for Africa), Addis Ababa, 111. https://www.researchgate.net/profile/264839419

[11] Chiduwa, G., Chimonyo, M., Halimani, T.E., Chisambara, S.R. and Dzama, K. (2008) Herd Dynamics and Contribution of Indigenous Pigs to the Livelihoods of Rural Farmers in a Semi-Arid Area of Zimbabwe. Tropical Animal Health and Production, 37, 333-344. https://www.ncbi.nlm.nih.gov/pubmed/18422255

[12] SAS (Statistical Analysis System) (2011) SAS Version 9.3. Procedure Guide. SAS Inc., Cary.

[13] Luke, M. (2010) Sheep Production Practices, Flock Dynamics, Body Condition and Weight Variation in Two Ecologically Different Resource Poor Communal Farming Systems. M.Sc. Thesis, University of Fort Hare, Alice. http://www.secheresse.info/spip.php?article44620

[14] Bushara, I., Hind Salih, A. and Mudalal, M.O. (2017) Birth and Weaning Weight of Sudanese Desert Goat as Affected by Management System. International Journal of Animal Husbandry and Veterinary Science, 2, 10-11. http://www.ijahvs.org/index.php/issues?view=publication\&task13

[15] CSA (Central Statistical Agency) (2012) Central Statistical Agency of the Federal 
Democratic Republic of Ethiopia. Agricultural Sample Survey of 2011/12 (2004 E.C). Volume II. Report on Livestock and Livestock Characteristics (Private Peasant Holdings), Central Statistical Agency, Addis Ababa.

[16] Kocho, T., Abebe, G., Tegegne, A. and Gebremedhin, B. (2011) Marketing Value-Chain of Smallholder Sheep and Goats in Crop-Livestock Mixed Farming System of Alaba, Southern Ethiopia. Small Ruminant Research, 96, 101-105. https://doi.org/10.1016/j.smallrumres.2011.01.008

[17] Tsedeke, K. (2007) Production and Marketing of Sheep and Goats in Alaba, SNNPR. M.Sc. Thesis, Hawassa University, Awassa. https://cgspace.cgiar.org/bitstream/handle/10568/726

[18] Getahun, L. (2008) Productive and Economic Performance of Small Ruminant Production in Production System of the Highlands of Ethiopia. PhD Thesis, University of Hohenheim, Stuttgart-Hoheinheim.

[19] Dibissa, N. (2000) Sheep Production on Smallholder Farms in the Ethiopian Highlands-A Farming System Approach. PhD Thesis, Humboldt University, Berlin.

[20] Lebbie, S.H.B. and Ramsay, K. (1999) A Perspective on Conservation and Management of Small Ruminant Genetic Resources in the Sub-Saharan Africa International Livestock Research Institute, Pretoria. South Africa. Journal of Small Ruminant Research, 34, 231-247. https://doi.org/10.1016/S0921-4488(99)00076-0

[21] Sölkner, J., Grausgruber, H., Okeyo, A.M., Ruckenbauer, P. and Wurzinger, M. (2008) Breeding Objectives and the Relative Importance of Traits in Plant and Animal Breeding: A Comparative Review. Euphytica, 161, 273-282.

https://doi.org/10.1007/s10681-007-9507-2

[22] Assen, E. and Aklilu, H. (2015) Sheep and Goat Production and Utilization in Different Agro-Ecological Zones in Tigray, Ethiopia. Livestock Research for Rural Development, 24, 16.

[23] Alemu, A. (2015) On-Farm Phenotypic Characterization and Performance Evaluation of Abergelle and Central Highland Goat Breeds as an Input for Designing Community-Based Breeding Program. M.Sc. Thesis, Haramaya University, Dire Dawa, 31-37.

[24] Talore, D.G., Girma, A., Azage, T. and Gemeda, B.S. (2018) Factors Affecting Sheep and Goat Flock Dynamics and Off-Take under Resource-Poor Smallholder Management Systems, Southern Ethiopia. Journal of Biology, Agriculture and Health care, 8, 2224-3208. http://www.iiste.org

[25] Ahmadu, B. and Lovelace, C.E.A. (2002) Production Characteristics of Local Zambian Goats under Semi-Arid Conditions. Small Ruminant Research, 45, 179-183. https://doi.org/10.1016/S0921-4488(02)00098-6

[26] Muasya, T.K., Githinji, M.G., Mugambi, J.N. and Ilatsia, E.D. (2014) Effect of Inbreeding on Growth Performance of Dual Purpose Goats in Semi-Arid Kenya.

[27] Deribe, G. (2009) On-Farm Performance Evaluation of Indigenous Sheep and Goats in Alaba, Southern Ethiopia. M.Sc. Thesis, Hawassa University, Awassa, 10-14.

[28] Dubekulu, L. (2015) Characterisation of Goat Production Systems in Selected Coastal Areas of the Eastern Cape Province, South Africa. M.Sc. Thesis, University of Fort Hare, Cape Town.

[29] Belete, S. (2009) Production and Marketing Systems of Small Ruminants in Goma District of Jimma Zone, Western Ethiopia. M.Sc. Thesis, Hawassa University, Hawassa. https://cgspace.cgiar.org/handle/10568/675

[30] Masika, P.J. and Mafu, J.V. (2004) Aspects of Goat Farming in the Communal 
Farming Systems of the Central Eastern Cape, South Africa. Journal of Small Ruminant Research, 52, 161-164. https://doi.org/10.1016/S0921-4488(03)00256-6

[31] Jemal, G. (2008) Phenotypic Characterization and Performance Evaluation of Abergelle Goat under Traditional Management System in Tanqua-Abergelle District of Tigray, Ethiopia. M.Sc. Thesis, Mekelle University, Mekelle.

[32] Hailu, D., Miesu, G., Nigatu, A., Futa, D. and Gamada, D. (2006) The Effect of Environment Factors on Pre-Weaning Survival Rate for Borana and Arsi-Bale Kids. Journal of Small Ruminant Research, 66, 291-294. https://doi.org/10.1016/j.smallrumres.2005.09.024

[33] El-Abid, K.E.H. and Abu-Nikhaila, A.M. (2009) Study on Some Factors Affecting Mortality Rates in Sudanese Nubian Kids. International Journal Dairy Science, 4, 74-79. https://doi.org/10.3923/ijds.2009.74.79

[34] Berhane, G. and Eik, L.O. (2006) Effect of Vetch (Viciasativa) Hay Supplementation to Begait and Abergelle Goats in North Ethiopia in Reproductive and Growth Rate. Small Ruminant Journal, 64, 233-240.

https://doi.org/10.1016/j.smallrumres.2005.04.020 https://eurekamag.com/pdf/004/004513041.pdf

[35] Muchadeyi, F.C., Sibanda, S., Kusina, N.T., Kusina, J. and Makuza, S.M. (2005) Village Chicken Flock Dynamics and Contribution of Chickens to Household Livelihoods in a Smallholder Farming Area in Zimbabwe. Tropical Animal Health and Production Journal, 37, 333-344. https://doi.org/10.1007/s11250-005-5082-5

[36] Meza-Herrera, C.A., Calderon-Leyva, G., Soto-Sanchez, M.J., Abad-Zavaleta, J., Serradilla, J.M., Garcia-Martinez, A., Rodriguez-Martinez, R., Veliz, F.G., Macias-Cruz, U. and Salinas-Gonzale, H. (2012) The Expression of Birth Weight Is Modulated by the Breeding Season in a Goat Model. Annals of Animal Science, 12, 237-245. https://doi.org/10.2478/v10220-012-0020-8

[37] Paez-Lama, S., Egea, V., Grilli, D., Fucili, M., Allegretti, L. and Guevara, J.C. (2013) Growth and Economic Performance of Kid Production under Different Rearing Systems and Slaughter Ages in Arid Areas of Argentina. Small Ruminant Research, 110, 9-14. https://doi.org/10.1016/j.smallrumres.2012.08.005

[38] Paez-Lama, S., Grilli, D., Egea, V., CerónCucchi, M., Fucili, M., Allegretti, L. and Guevara, J.C. (2015) Effect of the Rearing System on the Establishment of Different Functional Groups of Microorganism in the Rumen of Kid Goats. Acta Veterinaria, 65, 175-190. https://doi.org/10.1515/acve-2015-0015 